\title{
Policy Coordination of Aluminum Industrial Waste Management in Jombang Regency
}

\author{
Badrudin Kurniawan ${ }^{1, *}$, Tjitjik Rahaju ${ }^{2}$, Indah Prabawati ${ }^{3}$, Tauran ${ }^{4}$, Nabilah Ivana ${ }^{5}$ \\ 1,2,3,4,5 Department of Public Administration, State University of Surabaya, Surabaya, Indonesia \\ * Email: badrudinkurniawan@unesa.ac.id
}

\begin{abstract}
Environmental problems are complex and interlinked. It is necessary to adopt an integrative approach to understand it. Furthermore, it requires an integrated multi-sectoral approach to be overcome. Environmental policy integration (EPI) is needed to address the issue through inserting environmental aspects and objectives into sectoral policy for instance energy, agricultural, transportation, industry, and tourism policy. Policy coordination takes a salience role of harmonizing sectoral policy with environmental considerations and objectives. In the Jombang Regency case, huge of hazardous and toxic waste is generated by small industries include aluminum industries. The aluminum slag is produced by the industries every day and dumped spreadly over 118 locations. Currently, some agencies do coordinate to manage aluminum industrial waste. The policy coordination is able to synergize each sectoral policy toward appropriate waste management. The study aims to discuss the coordination between agencies on aluminum industrial waste management in Jombang Regency. The research adopts a qualitative approach so it is necessary to hold some interviews with some key informants from some local agencies. Furthermore, some development plan documents are gathered as well. Based on the discussion, policy coordination between agencies is quite important to integrate environmental policy objectives into sectoral policy. Furthermore, learning-oriented coordination benefits planning-oriented coordination.
\end{abstract}

Keywords: Environmental policy integration, Policy coordination, Aluminum industrial waste.

\section{INTRODUCTION}

Environmental problems are complex and interlinked. It means that the problems are result of interrelation between environmental factors and non-environmental factors. Consequently, it is necessary to use an integrative approach to understand such a problem [1]. Its multi-sectoral characteristic also makes this problem not only able to be overcome by environmental policies but also requires support from other sector policies. Eventually, the problems has to be overcome by an integrated multi-sectoral strategy.

Environmental Policy Integration (EPI) is a way to solve environmental problems with an integrated approach. EPI refers to the integration of environmental aspects and policy objectives into sector policies such as energy and agricultural policy, and has also been referred to as sector integration [2]. Not only the integration of environmental aspects and objectives in energy and agricultural sector policies, but also in the policies of the transportation, industry, tourism, infrastructure and other sectors. EPI is also considered as an effort to prevent environmental problems being happened. The European Environment Agency (EEA) asserts EPI as a process of shifting the focus of environmental policy away "from environmental problems them selves to their causes... and from "end of pipe" environment ministries to "driving force" sector ministries [3]

Environmental Policy Integration requires inter-agency policy coordination in order to synergize those multi-sectoral policies. Dupont and Jordan [4] argue EPI is a principle that is and/or should be implemented in practice in the means of making policy (coordination), in the assessment of potential policy outputs or decisions (coherence) and in the implementation or outcome of policy decisions (impact). Policy coordination has a very important role because it is the first step to ensure environmental aspects are included in the policy-making process of other sectors. EPI also claims that effective coordination mechanisms will "green" public (infrastructure) expenditure and sector market orders [5]

Furthermore, policy coordination provides many benefits. Perri 6 refer to coordination as '.. the development of ideas about joint and holistic working, joint information systems, dialogue between agencies, processes of planning, and making decisions' [6]. Policy coordination is necessary to overcome policy fragmentation [7]. Additionally, Peters argues that there are some reasons showing the urgency of the policy coordination. The coordination is necessary in order to avoid duplication and contradiction among programs; to prevent the policy output of certain organization create problems for other 
organization; to emphasize horizontal management: to integrated public service; to overcome cross cutting problems, and to improve the image of public sector [8]

Jombang is one of the regencies in Indonesia where many industries grow, especially small and medium industries. In addition to providing jobs, this type of industry also produces hazardous and toxic waste, such as waste released by the aluminum industries. Those industries that have been established for decades treat waste from large companies in the form of aluminum dross. Next, this type of waste is processed and then turned into many aluminum bars. In the processing process, those industries also produce waste in the form of aluminum slag. Based on Government Regulation Number 101 of 2014 concerning Management of Hazardous and Toxic Waste, both types of waste are classified as hazardous and toxic waste [9]

This aluminum slag is produced by 136 home industries every day. This waste is stockpiled and stacked freely exposed to water, air, and soil adjacent to settlements and productive land. The existence of this waste has a negative impact on the environment, namely polluting water, soil and air, as well as on the health of residents, which causes respiratory problems (Arisandi, 2018). Based on the results of a study conducted by the Ministry of Environment and Forestry (MEF), the data obtained were approximately spread over 118 locations where aluminum slag was dumped. Of these 118 points, 11 locations have been identified with an area of $51,367 \mathrm{~m} 2$, the volume of soil contaminated with B3 waste is around $96,470 \mathrm{~m} 3$, or around 146,828 tons [10].

One of the efforts of the Jombang Regency Government to overcome this pollution is the development of small aluminum industries centers. This industrial center is created to facilitate the management of aluminum slag. The local government will build a waste treatment plant in the industrial area. In this case, the Department of Trade and Industry is the leading sector in implementing this program. This indicates that the aspects and objectives of environmental policy are integrated into the industrial sector policy. This program is organized in collaboration between the Department of Trade and Industry, the Inspectorate, the Department of the Environment, the Department of Public Works, and the Regional Development Planning Agency of Jombang Regency.

Based on the previous explanation, the author is interested in scrutiny the policy coordination on the development of an aluminum industrial center in the Jombang Regency. The research question developed in this study is how the coordination between agencies on aluminum industrial waste management in Jombang Regency proceed. Then, researchers determine the focus of research, namely on the integration of environmental aspects and objectives in the industrial sector policy and coordination between agencies on aluminum industrial waste management in Jombang Regency.

\section{METHODS}

This research can be categorized as qualitative research. The researcher conducted interviews with several official employees from the Department of Trade and Industry, the
Department of the Environment, the Department of Cooperatives and Micro Enterprises and the Regional Development Planning Agency of Jombang Regency. In addition, the researchers also collected secondary data such as the Strategic Environmental Assessment for the Regional Medium-Term Development Plan for 2018-2023, the Strategic Environmental Assessment for the Regional Spatial Plan 20192039, Strategic Plan of Department of Environment 20182023, Strategic Plan of Department of Trade and Industries 2018-2023, Strategic Plan of Department of Cooperative and Micro Industries 2018-2023, the Preliminary Detail Engineering Design (DED) for the aluminum industries center, and Decree of the Regional Secretary of Jombang Regency regarding the Technical Team for the Development of Aluminum Slag Small and Medium Industries Center.

Data analysis is done by categorizing the obtained data. Categorization of data is done based on the research focus that has been determined. Both data from interviews and institutional documents are used to describe how the integration of environmental aspects and objectives is carried out in policies for the development of the aluminum industrial center. In addition, the data obtained is also used to describe the coordination between agencies in making policies for the development of the aluminum industrial center and the approach.

\section{RESULTS AND DISCUSSION}

\subsection{The Management of Aluminum Industrial Waste in Jombang Regency}

Jombang Regency is one of the regencies in East Java Province. The area of this regency is 115,950 hectares, consisting of 21 sub-districts and 306 villages. Almost half of the area is agricultural area, which is $51,430.69$ hectares or $49.7 \%$ of the total area. The agricultural area in this regency is divided into: $38,066.59$ hectares of rice fields, the largest area of rice fields is in Bareng Sub-District with an area of 5,540.81 hectares, while other agricultural areas are moor with an area of 13,364.10 hectares. The widest moor area is in Wonosalam Sub-District with an area of 4,090.20 hectares [11]

In addition to agriculture, industrial development in Jombang Regency is also quite fast. The types of industries that develop in this district include small, medium and large industries. Industrial activities tend to develop towards small industrial activities and manufacturing industries. In 2017, the total area of land use for industry reached 410 hectares. The three sub-districts with the most land area for industry are Jombang District (98 hectares), Ploso District (57 hectares), and Ngoro District (49 hectares) [11].

Both Sumobito and Kesamben are not sub-districts that have the largest number of industries. However, in these two sub-districts, the small aluminum industries grow rapidly. As a result, The production of aluminum slag is also very large. This type of waste pollutes the surrounding environment because it is not managed properly. Many community groups also pay serious attention to this issue. Therefore this problem was accommodated as one of the sustainable development issues in the document of Strategic Environmental Assessment for the 
Medium Term Plan of the Jombang Regency 2018-2023. This document then also contains recommendations for the Jombang Regency Government so that in the future the government needs to develop a program for controlling hazardous and toxic waste in order to ensure responsible consumption and production (the twelfth sustainable development goal). The document also recommends the Environment Agency as the person in charge of the program because this is also the main task of the agency [12]

In the Strategic Plan of Environmental Agency 2018-2023, the issue of aluminum slag pollution is also a strategic issue. Although in 2013, the agency has prepared an Environmental Impact Analysis for Aluminum Industrial Estates, nevertheless there are still many unresolved issues. The pile of aluminum slag is increasingly spreading and polluting the environment. Ironically, this pollution extends to other sub-districts such as Jogoroto and Diwek sub-districts. This agency also establishes a Program for Control, Supervision, and Enforcement of Environmental Law, including the case of aluminum slag [13].

The location of the aluminum industries that are spread out causes efforts to control aluminum slag pollution not easy to implement. The involvement of other agencies, such as the Department of Trade and Industry, is also very much needed because this agency is responsible for industrial governance in Jombang. In the 2018-2023 Strategic Plan document, this service establishes the Creative Industry and Green Industry Guidance and Development Program. Based on the Decree of the Regional Secretary of Jombang Regency, this Service is also assigned to be the leading sector in the development of small aluminum industrial centers in Sumobito District. The results of Strategic Environmental Assessment (SEA) recommend that this aluminum industrial center be placed in a centralized area, away from settlements and rice fields/livestock or similar activities [14]

In the Strategic Plan of the Department of Cooperatives and Micro Enterprises, the Program for Institutional Quality Development and Cooperative Business is established. In the development of aluminum industrial centers, the industry must be in the form of a limited company or incorporated as a member of a cooperative. The local government helps fulfill the technical requirements to obtain a business license if the industry is willing to join as a member of the cooperative. Based on Government Regulation Number 22 of 2021 concerning Implementation of Environmental Protection and Management, Business Licensing is the legality granted to Business Actors to start and run their business and/or activities. Meanwhile, business actors must obtain environmental approval before obtaining the business license. However, the government also allows industries that do not want to join cooperatives. The industry must become a limited liability company and meet various technical requirements to obtain the permit. If the industry does not get the permit, the industry will be prohibited from operating. In this case, the Department of Cooperatives and Micro Enterprises provides institutional guidance for industries who are willing to become members of cooperatives [15].

\subsection{Coordination among Local Agencies within Aluminum Industrial Waste Management}

Debates around coordination approaches are often framed around the use of more planning or learning-based elements. Each approach has some different key components. Learningorientated coordination involves some components as appraisal of policy, risks, and vulnerability; stakeholder engagement; boundary organizations and independent advisory panels; knowledge portals; and evaluation Furthermore, planning orientated coordination has some components for instance leadership, inter-ministerial committees, cross-sectoral strategies, action and implementation plans [16].

Learning-oriented coordination is carried out by agencies by holding meetings with the community. Meetings between the Regional Development Planning Agency, several related agencies, sub-district office employees, village governments, and residents who work in the aluminum small industries were held quite often in 2017. Several of these meetings were also held at the industrial location so that more residents could attend. In this meeting, residents conveyed their perspectives on the existence of this aluminum industry. They said that the small industries have been their source of income for years and they are very dependent on the existence of those industries. The community is also willing if the location of their business is centralized. In addition, they are also willing to donate land contaminated with aluminum slag, which they previously purchased, to the local government to be used as an aluminum industrial center area.

The coordination meeting made it clear that the poor management of aluminum slag waste is a cross-cutting issue, which is not limited to environmental issues but is also an economic issue. The community is very dependent on the existence of the aluminum slag industries as their source of income. They are also willing to be actively involved in realizing better aluminum slag aluminum waste management. Local governments are required to produce policies that are able to accommodate these two interests, both the interests of environmental protection and the economy of the community.

Coordination meetings between agencies, consultants and the Ministry of Environment and Forestry were also held. The cost-benefit analysis conducted by the consultant confirms that this industrial center can provide economic benefits to the community in addition to providing benefits in the form of environmental protection. In addition, the results of the coordination meeting also provide a solution for the limited funds owned by the district government to support the development of these industrial centers. The district government needs to apply for a Special Allocation Fund to the Ministry of Industry by fulfilling various requirements, one of which is that small industries become members of cooperatives.

The learning outcomes obtained provide many benefits to planning-oriented coordination. Those help to (1) clarify the characteristics of the problem; (2) increase opportunities to solve problems, and (3) provide a scientific basis for a policy. All benefits could support creating effective and efficient development planning, a multi-sectoral strategy, and legitimate policies. 
The planning-oriented coordination is carried out in several ways, for example by holding an annual inter-departmental coordination meeting organized by the Regional Development Planning Agency of Jombang Regency. This meeting discussed the programs that will be implemented by all sectoral agencies in the next year. the Regional Development Planning Agency ensures that the programs to be implemented by the sectoral agencies are in accordance with the targets set in the Regional Medium Term Development Plan. The policy for managing aluminum slag waste has an important role in achieving the twelfth goal of the Sustainable Development Goals (SDGs), namely responsible production and consumption. The meeting also discussed the problems that are the main reasons for a program to be developed, such as the official programs that lead to the management of aluminum slag waste. The Environment Agency establishes a land restoration program for the area where the industrial center will be built. The Agency of Trade and Industry makes a Detailed Engineering Design and feasibility study for the development of the industrial center. The cooperative office provides guidance to small industries owners on how to form and manage cooperatives. In addition, the meeting also discussed the budget for the planned program. The discussion of the program budget is accompanied by the Regional Financial and Asset Management Revenue Agency.

In addition to the annual inter-departmental meeting, policy coordination is also carried out through informal communication both offline and online. Informal offline communication is usually done when the agency's personnel meets each other unplanned. In addition, communication can also be done via WhatsApp group. This WhatsApp group is a medium of communication between the Regional Development Planning Agency and other sectoral agencies within its control range. Informal communication carried out through these two methods also discussed the problem of aluminum slag and program plans to be implemented. However, this formal discussion must be followed by a formal meeting to agree on a program plan for next year.

\section{CONCLUSION}

The management of aluminum slag waste requires policy coordination between agencies in Jombang Regency. The results of the policy coordination are contained in the department's strategic plan. The document shows that the programs of several agencies are programs that synergize with each other in managing aluminum slag waste. In addition, this policy coordination is not only oriented to policy planning. However, it is also oriented to inter-departmental learning. Learning-oriented policy coordination benefits planningoriented coordination. The results of the coordination provide awareness and affirmation that the management of aluminum slag waste is a cross-cutting issue that requires multi-sectoral strategies to overcome.

\section{ACKNOWLEDGMENT}

Thanks to State University of Surabaya which gave the research grant. Also, thanks to Jombang Regency Governmentwho have supported this research.

\section{REFERENCES}

[1] C. Asdak, Kajian Lingkungan Hidup Strategis: Jalan Menuju Pembangunan Berkelanjutan, Yogyakarta: Gadjah Mada University Press, 2014.

[2] Å. Persson, "Environmental policy integration: An introduction," Stockholm Environment Institute, Stockholm , 2004.

[3] EEA, "Environment in the European Union at the Turn of the Century," EU Publications, Copenhagen, 1999.

[4] C. Dupont and A. Jordan, "Policy Integration," in Environmental Policy in the EU: Actors, Institutions and Processes, London, Routledge, 2021, pp. 203-219.

[5] C. Hey, "Why does environmental policy integration fail? the case of environmental taxation for heavy goods vehicles," in Environmental Policy Integration: Greening Sectoral Policies in Europe, London, Earthscan Publication, Ltd, 2002, pp. 127-152.

[6] P. 6, "Joined-up government in the western world in comparative perspective, a preliminary literature review and exploration," Journal of Public Administration Research and Theory, vol. 14, no. 1, p. 103-38, 2004.

[7] D. T. Peters, E. H. Klijn, K. Stronks and J. Harting, "Policy coordination and integration, trust, management and performance in public health-related policy networks: a survey," International Review of Administrative Science, vol. 0, no. 0, pp. 1-23, 2015.

[8] B. G. Peters, "The challenge of policy coordination," Policy Design and Practice, vol. 1, no. 1, pp. 1-11, 2018.

[9] P. Arisandi, Jejak Beracun, Gresik: Ecoton-Detox, 2018.

[10] M. o. E. a. Forestry, "Pemulihan lahan terkontaminasi limbah bahan berbahaya dan beracun di kabupaten jombang, jawa timur," 2019. [Online]. Available: http://pslb3.menlhk.go.id/read/pemulihan-lahanterkontaminasi-limbah-bahan-berbahaya-dan-beracun-dikabupaten-jombang-jawa-timur. [Accessed 2 September 2021].

[11] Strategic Environmental Assessment for the Regional Spatial Plan 2019- 2039.

[12] Strategic Environmental Assessment for the Regional Medium-Term Development Plan for 2018-2023.

[13] Strategic Plan of Department of Environment 2018-2023.

[14] Strategic Plan of Department of Trade and Industries 2018-2023.

[15] Strategic Plan of Department of Cooperative and Micro Industries 2018-2023.

[16] D. Russel and e. al, "Policy coordination for national climate change adaptation in europe: all process, but little power," Sustainability, vol. 12, pp. 1-18, 2020. 